\title{
Determinants of Implementation of Public-Private Partnership in Poland: the Case of Transport Infrastructure
}

\author{
Beata Zagozdzon \\ Faculty of Transport and Electrical Engineering, Kazimierz Pulaski University of Technology and Humanities in Radom, 26-600 Radom, \\ Poland \\ *Corresponding Author: b.zagozdzon@pr.radom.pl
}

Copyright $(2013$ Horizon Research Publishing All rights reserved.

\begin{abstract}
One of the models of financing public investments, especially transport infrastructure, is a public-private partnership (PPPs). The European Commission has been supporting this formula of implementing transport investments for more than ten years. The PPP formula is very important for the "new" EU countries from Central Europe, because it helps bridge the gap between the investment needs and the financial resources that are available in these countries. However, achieving success in the practical implementation of PPP requires the creation of appropriate conditions supporting this concept. The aim of this article is to identify determinants of implementation of PPP in the area of transport infrastructure and to present an analysis of the influence of these factors on the development of partnership in Poland. Research in the available literature has made it possible to identify three main groups of the determinants of PPP: the government's economic doctrine which includes the macroeconomic condition of the economy, the legal system, and the capacity of public institutions. The analysis confirmed that these determinants are important for the implementation of transport projects in Poland. The research also indicated that strong government support is particularly important for the development of the Polish PPP market. The government should initiate the formulation of appropriate legal regulations and create public institutions, whose purpose is to advise and support local public authorities in the practical implementation of PPP.
\end{abstract}

Keywords Public-private partnership, transport, PPP in Europe, Poland

\section{Introduction}

Over the last few decades, economists dealing with problems of transport infrastructure have believed that this infrastructure is no longer perceived as a public product and should not be provided only by the state $[1,2]$. The private sector should participate in the implementation of transport infrastructure projects which have been the domain of activities of public authorities so far. One of these assumptions is a concept of public-private partnership PPP, as one of the models of financing public investments. Since the topic of PPP is quite well known and many publications have already addressed it, the article does not cover a broader discussion on the nature and forms of partnership. It only gives a general definition of PPP, formulated based on different definitions of the term that can be found in the literature devoted to the topic $[3,4,5]$. Public-private partnership is a kind of agreement between a government and a private partner. They work together on the implementation of a project. However, they have their own interests and try to achieve their own goals. The partners cooperate using clearly defined allocations of risk and responsibilities. The cooperation should result in a lower cost of the undertaking and a higher quality of services than when it is financed in the traditional way from public funds [6]. The form of private partners' involvement in PPP projects depends on the specificity of the given project and individual needs of project participants. The detailed classification of PPP forms have been presented by i.a. R.Mu, M.de Jong and E. ten Heuvelhof [7]. At this point, it is only worth mentioning the main forms of private partner's participation in infrastructure projects: BOT - Build, Operate, Transfer (to the public sector after a few years since the project was launched), DBFO - Design, Build, Finance, Operate and BOO - Build, Own, Operate (in this case the private partner never stops to be the owner).

For more than ten years, partnership has been an area of particular interest for the European Commission in the context of the construction of TEN - Trans-European Network. The networks plays a key role in the process of European integration [8]. The need to modernize transport infrastructure is a major concern especially in Poland and other Central European countries [9]. The infrastructure in these counties is not technically suited to the current 
transport needs and is a barrier to their economic development and full integration. Heavy capital expenditures, which must be made in a short time, are required to solve the problem. The World Bank estimates that a total of 65 billion euros should be allocated for infrastructure investment in the new EU member states in the period 2007-2032. It also notes that Poland has the greatest needs -21.4 billion euro [10]. In the opinion of the European Commission, PPP may help to bridge the gap between investment needs and funds that a country is able to invest [11]. It actively supports and promotes the use of partnership, which is evident in directives, communications and studies conducted for the European Commission - Guidelines for Successful Public Private - Partnerships [12], Resource Book on PPP Case Studies [13], A Guide to Guidance. Sourcebook for PPPs [14]. In a document published in 2011 - "White Paper. Roadmap to a Single European Transport Area - Towards a competitive and resource efficient transport system', the European Commission states that "diversified sources of finance both from public and private sources are required", and that ,,unlocking the potential of private finances equally requires an improved regulatory framework and innovative financial instruments" $[15]$. Therefore, improving the way in which private funding in the PPP model is combined with EU funds is a very important topic in the programming period 2014-2020. On the initiative of the European Commission, the European PPP Expertise Centre develops guidelines that will help to more effectively combine PPP model with EU funds.

All activities that promote PPP are important, because, as the practice of using the formula shows, gaining tangible benefits, without suffering significantly negative consequences of implementing such projects, is much more difficult than the literature indicates [16]. Here, it is worth mentioning known examples of failure in Europe, which are the Euro tunnel project and the Oresund Bridge. At the same time, since the 90 's of the $20^{\text {th }}$ century, transport projects have had the highest share in the total value of the European PPP market [17]. An effective implementation of partnership in practice requires appropriate economic and institutional conditions $[18,19]$.

The purpose of this article is to identify factors which determine the implementation of public-private partnership of transport infrastructure, as well as analyse the influence of these factors on the development of partnership in Poland. Identification of these determinants should help create an environment that is more conducive to the implementation of PPP, and thus speed up the process of infrastructure modernization as well as the process of European integration.

\section{Theory - Determinants of Implementation of PPP}

The evolution of economic theory towards economic liberalism, observed since the 1970s, has accelerated the processes of deregulation and privatization. Also due to the economic crisis occurring in the 1980s, states started considering the private sector to be a source of financing public investment [20]. The conservative governments in Great Britain and the United States had a great influence on the intensity of privatization and deregulation processes. Governments led by Margaret Thatcher and Ronald Reagan are well known for following free market policies based on the school of thought of Hayek and Friedman. Empirical studies indicate that right-wing governments give economic freedom and compel advanced privatization [21,22]. The ideology of the government has a strong influence on the processes of deregulation and privatization in the OECD countries $[23,24]$.

A doctrine, economic ideology adopted by the government determines how all elements of the economic system of the country work. However, only those which affect the success of PPP transport projects will be discussed. Studies show that a significant factor is the stability of the country, determined on the basis of its macroeconomic condition. Good macroeconomic conditions are able to attract investors and increase the level of financial resources [25]. This factor has particular significance for developing countries for which the participation of foreign private investors is very important. A stable macroeconomic situation and favourable political conditions created by the government cause that the partnership is being used on an increasing scale. According to the studies conducted by P.Galilea and F.Medda [19], experience in carrying out PPP transport infrastructure projects is one of the major determinants of success.

Equally important is the level of development of the financial market, as the private sector relies mainly on external financing when undertaking private-public partnership projects. Efficient financial inter mediation, unrestricted access to capital and financial services, which means a developed financial market, is the most important factor for the success of PPP projects. Multilateral lenders' and credit agencies' involvement in the project reduces the risk of failure [26]. Another factor is the level of the competition of private investors and, associated with it, the level of competition of the public procurement market. The intensity of competition in the public procurement market means a high number of offers being made, which offers the opportunity to select a better supplier and conduct ex-ante evaluation.

Other factors that affect the efficiency of PPP projects also include the level of corruption [19]. Public procurement for large-scale projects, like transport infrastructure, is the area particularly susceptible to corruption and collusion. Even in the country as unblemished as Sweden some cases of collusion with a constructor were detected and confirmed. Irregularities and exceeding spending limits were also reported in the Netherlands [27]. As these two countries are high on the list of Transparency International, and thus have a high level of trust, it can be concluded that corruption is much more widespread in the countries with much poorer 
reputation, like Italy or Bulgaria [7].

The consequence of the government's economic policy is a legal and institutional system. Legal regulations and high quality of institutions are the primary determinant of the success of PPP projects. According to studies, partnership is more common in countries with strong and effective legal institutions as well as in countries where the rights of investors are well protected by regulations [18]. Additionally, the analysis carried out for the European Commission shows that legislation is the first step towards successful implementation of PPP arrangements [13,28]. What is important for investors is the stability of contracts including stipulations about the project. Therefore, the quality of institutions that make sure the law is obeyed is of great importance. It is worth mentioning here that the effectiveness of legal institutions is believed to have a far greater impact on the success of PPP projects than legal regulations [29]. Strong institutions ensure the quality of regulations and the security of PPP arrangements, thus reducing the risk faced by the country. This creates a good climate for investors and have a positive influence on the trust between the government and private entities. Mutual trust makes both the government and the private partner sure that the stipulations included in the contract will be applied. Trust between the government and the private investor is essential for the success of a PPP project [30].

Another important determinant of the implementation of PPP is the activity of government agencies and regional institutions in charge of PPP arrangements [18]. In the majority of countries with many years of experience in preparing and implementing projects, there are institutions promoting and popularizing PPP. They are usually public administration entities or stay under the supervision of the Ministry of Finance, Economy or Transport. They are largely, if not entirely, financed from public funds [13]. Advisory services provided by such agencies are particularly important in developing countries that have no experience in using this financing model.

The review of research and careful consideration show that there are many factors that affect the efficiency of the implementation of PPP projects. Yet, the crucial point is the economic doctrine (ideology) of the government, which translates into the macroeconomic situation, market conditions, legal and institutional system. Therefore, the following determinants have been selected for further analysis:

- The government's economic policy, including experience with PPP projects,

- Market conditions, including the level of development of the financial market and competition of the public procurement market,

- The legal system; and,

- Institutional preparation (institutional capacity).

Analysis of these determinants will be carried out on the example of Poland. Qualitative as well as quantitative methods were used to conduct the study. The former includes a comparative analysis and benchmarking, while the later includes a statistical analysis and an analysis of cause-effect relations. The use of quantitative and qualitative methods increases the accuracy of conclusions.

\section{Research and Results - Analysis of the Determinants of PPP in Poland in Respect of Transport Infrastructure}

\subsection{The economic situation of Poland and the specificity of transport}

The macroeconomic condition of the country and the stable economic conditions are important determinants of the implementation of PPP. This factor can attract investors and increase the level of private capital, which is particularly significant for developing countries. Therefore, it is reasonable that a study of the subsequent determinants of the implementation of PPP was preceded by the synthetic characteristic of the Polish economy. The basic macroeconomic indicators are presented in Table 1, Figures 1 and 2 . The statistical comparative analysis includes the EU as a whole and the selected countries. Since Poland is a relatively large EU country, which is classified in the sixth place in terms of population, the five largest EU countries have been chosen for the analysis. The studies also cover the Central European countries that began the process of restructuring their economies in the late 1980 s and the ones that entered the EU in 2004 and have the largest populations

Table 1. Basic economic indicators, 2011 [31]

\begin{tabular}{|c|c|c|c|c|c|}
\hline Country & $\begin{array}{c}\text { Population } \\
\text { million }\end{array}$ & $\begin{array}{c}\text { GDP } \\
\text { (nominal) } \\
€ \text { billion }\end{array}$ & $\begin{array}{c}\text { GDP per capita } \\
\text { in } €\end{array}$ & \multicolumn{2}{|c|}{$\begin{array}{c}\text { Member states external trade } \\
€ \text { billion }\end{array}$} \\
\cline { 4 - 6 } & & 12651,1 & 25100 & Exports & Imports \\
\hline EU27 & 501,7 & 1996,6 & 27200 & 4362,3 & 4451,2 \\
\hline France & 63,4 & 2592,6 & 30300 & 1058,6 & 512,8 \\
\hline Germany & 81,8 & 1579,7 & 25100 & 375,8 & 401,4 \\
\hline Italy & 60,8 & 1063,4 & 24100 & 220,1 & 268,5 \\
\hline Spain & 46,2 & 1750,4 & 27300 & 361,0 & 483,9 \\
\hline United Kingdom & 62,9 & 369,7 & 16200 & 135,6 & 151,3 \\
\hline Poland & 38,5 & 156,2 & 20200 & 117,0 & 109,3 \\
\hline Czech Republic & 10,5 & 99,8 & 16500 & 80,7 & 73,6 \\
\hline Hungary & 9,9 & 69,7 & 18400 & 57,5 & 5 \\
\hline Slovak Republic & 5,4 & & 57,6 \\
\hline
\end{tabular}




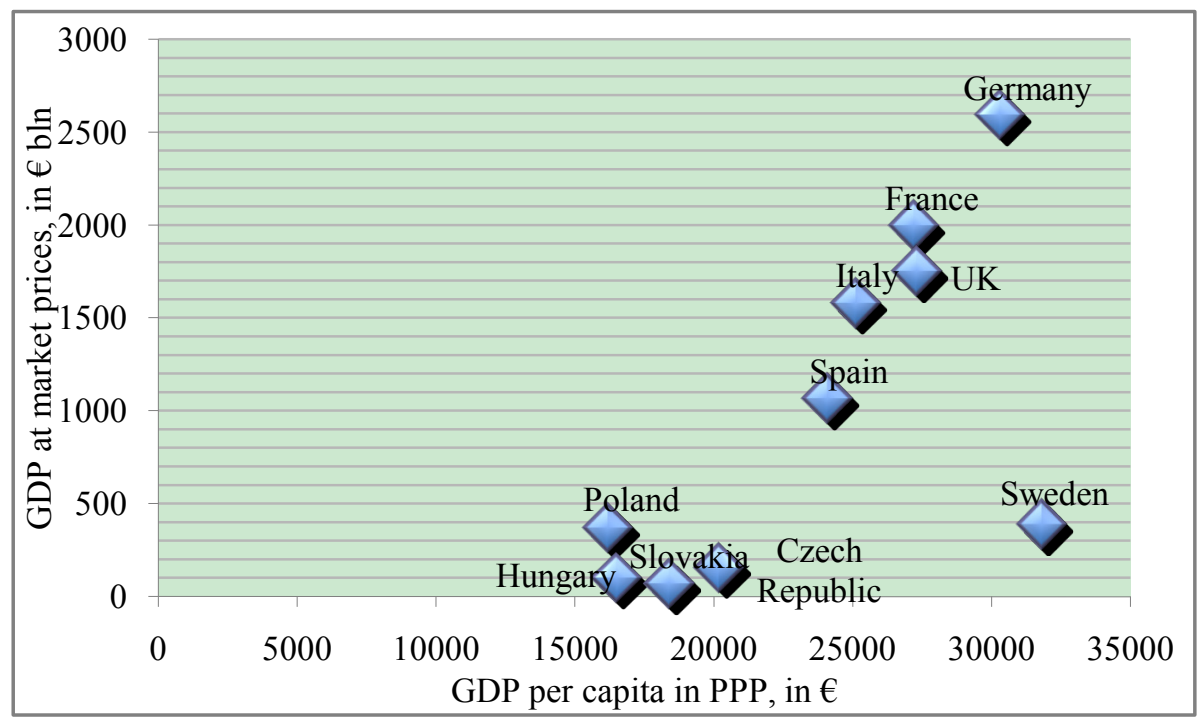

\begin{tabular}{|ccc|}
\hline & GDP per capita in PPP GDP at market prices \\
& 2011 & \\
EU27 & in Euro & in billion Euro \\
& 25100 & 12651 \\
Germany & 30300 & \\
Spain & 24100 & 2593 \\
France & 27200 & 1063 \\
Italy & 25100 & 1997 \\
& & 1580 \\
Sweden & 31800 & \\
United Kingdom & 27300 & 388 \\
Poland & 16200 & 1750 \\
Czech Republic & 20200 & 370 \\
Hungary & 16500 & 156 \\
Slovakia & 18400 & 100 \\
\end{tabular}

Figure 1. Correlation between GDP and GDP per capita, 2011 [31]

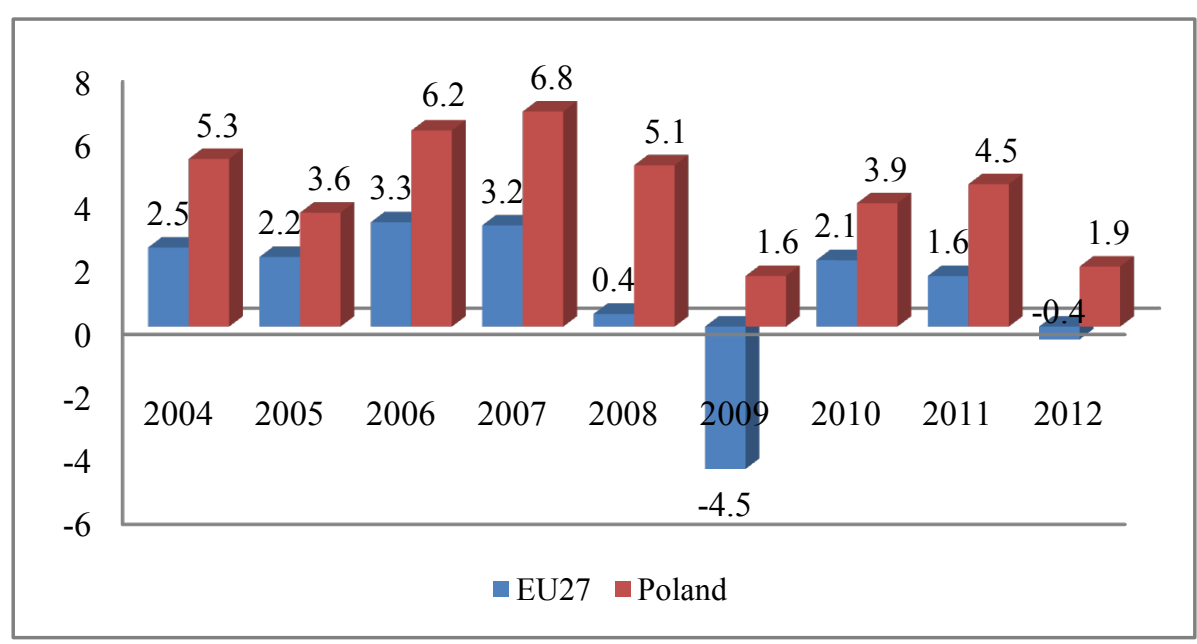




\begin{tabular}{|ccc|}
\hline \multicolumn{3}{|c|}{ Growth in GDP (real growth), \% change compared to previous year } \\
EU27 & Poland \\
2004 & 2.5 & 5.3 \\
2005 & 2.2 & 3.6 \\
2006 & 3.3 & 6.2 \\
2007 & 3.2 & 6.8 \\
2008 & 0.4 & 5.1 \\
2009 & -4.5 & 1.6 \\
2010 & 2.1 & 3.9 \\
2011 & 1.6 & 4.5 \\
2012 & -0.4 & 1.9 \\
\hline
\end{tabular}

Figure 2. Growth in GDP, \% change compared to previous year [31]

The Polish economy, taking into account the nominal value of GDP, is the ninth largest EU economy. This position is a logical consequence of the size of the country, its population, and area. This is particularly true since the GDP per capita constitutes an approximate measure of the economic potential of the country and its work efficiency is only $64 \%$ of the total EU27 value. This indicator has the lowest value among the investigated countries of Central Europe. The participation of Poland in the European export is also very small and amounts to $3 \%$. At the same time, a constant and progressing economic growth has been characterizing the Polish economy in the recent years. This was particularly visible in 2009 , when GDP rose by $1.6 \%$, which was the only positive result among the EU countries. Poland was called "the green island." Undoubtedly, the Polish economy stands out among the remaining countries with high dynamics of the economic growth. However, this growth is based mainly on the large domestic market, low labour costs, and funds from the EU.

While presenting basic information about the condition of the Polish economy, in the context of the fundamental topic of this article (the determinants of PPP), the position of the private sector is worth mentioning. The development of private economic activity began in the late 1980 's, and in the subsequent years, the private sector gradually strengthened its participation in key macroeconomic indicators, such as gross value added, investment outlays, foreign trade and employment. In 1995, the private sector contribution in creating gross value added was $63 \%$; however, in 2011, its share grew to $78 \%$. The remaining indicators have the following values [32]:

- private sector participation in export $-82 \%$,

- in investment outlays $-55 \%$,

- in sold production of industry $-86 \%$,

- in employment $-75 \%$.

Currently, the share of the private sector in GDP is approximately $80 \%$. This is not a significant contribution in comparison to the developed economies of Western Europe, where the share of the private sector in the creation of GDP at the beginning of 2000 exceeded $90 \%$ (from $98 \%$ in Great Britain, $95 \%$ in Ireland, to $87 \%$ in Sweden) [33].

Another issue, discussed as a part of the introduction to the fundamental research, is the specificity of the Polish transport. In general, the Polish transport market and the structure of transport do not differ much from the "old" European countries. As in developed EU countries, road transport is the dominant form of transport for cargo and passenger systems. Its share in cargo is about $80 \%$. Table 2 and Figure 2 show the quantities characterizing transport in Poland and selected EU countries. The focus was only on road and rail transport, since these types of transport signify $90 \%$ of passengers and cargo [31].

Table 2. Performance of freight and passenger transport, 2011 [31]

\begin{tabular}{|c|c|c|c|c|c|}
\hline \multirow{2}{*}{ Country } & \multicolumn{2}{|c|}{$\begin{array}{c}\text { Freight transport } \\
\text { thousand mio tkm }\end{array}$} & \multicolumn{3}{c|}{$\begin{array}{c}\text { Passenger transport } \\
\text { thousand mio pkm }\end{array}$} \\
\hline & rail & road & rail & passenger cars & buses\& coaches \\
\hline EU27 & 420,0 & 1734,1 & 407,1 & 4822,1 & 512,2 \\
\hline France & 34,2 & 185,7 & 89,0 & 812,7 & 51,1 \\
\hline Germany & 113,5 & 323,8 & 85,0 & 898,5 & 61,1 \\
\hline Italy & 19,8 & 142,8 & 43,3 & 665,8 & 103,2 \\
\hline Spain & 9,7 & 206,8 & 22,8 & 334,0 & 55,7 \\
\hline United Kingdom & 21,0 & 152,9 & 56,6 & 655,1 & 44,9 \\
\hline Poland & 53,7 & 207,6 & 18,2 & 313,2 & 20,7 \\
\hline Czech Republic & 14,3 & 54,8 & 6,7 & 65,5 & 15,8 \\
\hline Hungary & 9,1 & 34,5 & 7,8 & 52,3 & 16,5 \\
\hline Slovak Republic & 9,4 & 29,2 & 2,4 & 26,9 & 5,5 \\
\hline
\end{tabular}




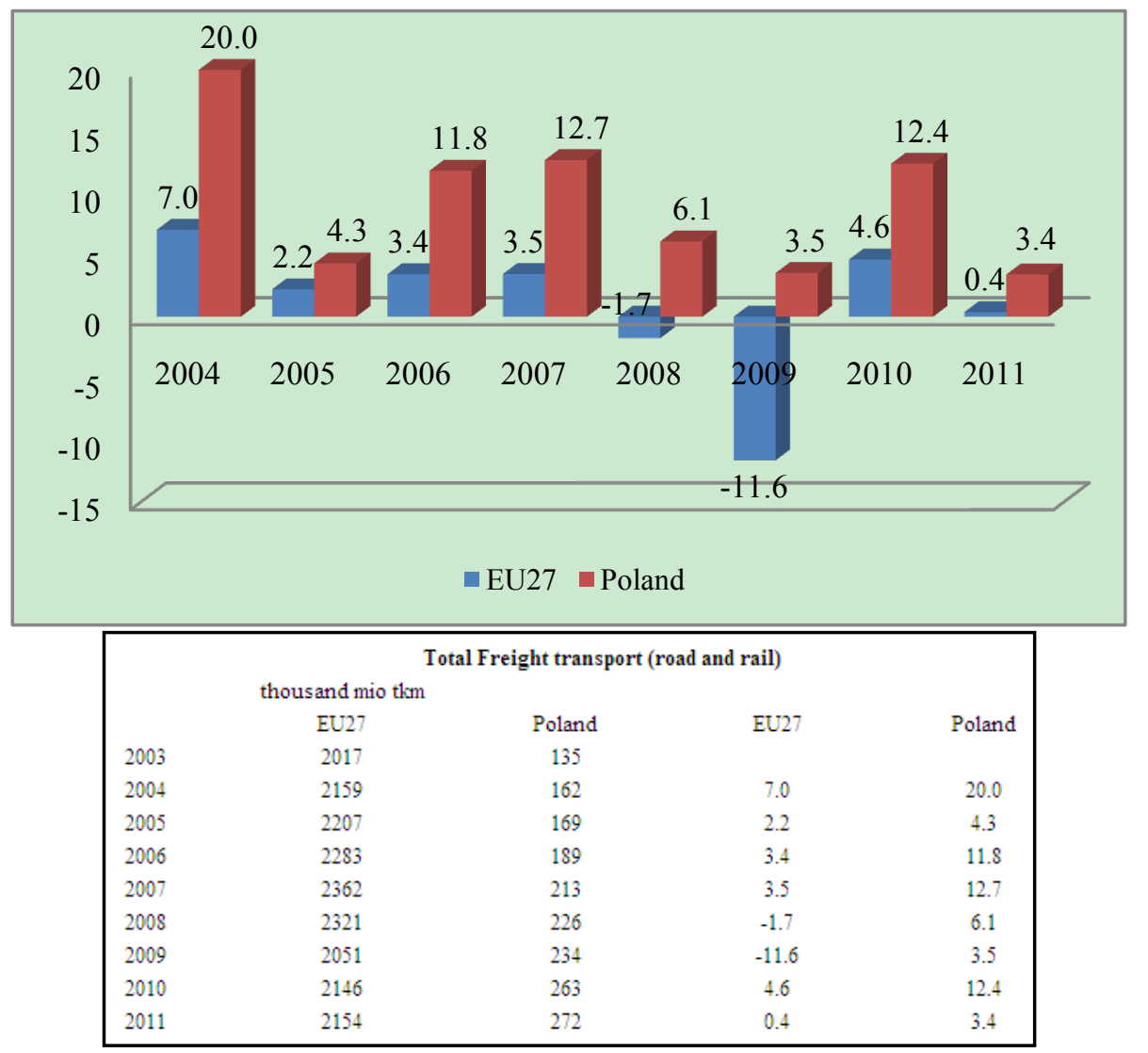

Figure 3. Growth in freight transport (road and rail, tkm), \% change compared to previous year [31]

Poland ranks second among the EU countries, after Germany, in transporting cargo by rail and road transport. Such a high position results from a strong demand in the domestic market and low labour costs, in comparison to the "old" EU countries, thanks to which carriers have a competitive advantage in the international market. The constant growth of transport is characteristic of freight transport, just like of the Polish economy.

However, as far as carriage of passengers is concerned, the high level of people travelling by cars is worth emphasizing. In Poland, the individual motorization rate has been dynamically increasing since the beginning of 1990. This phenomenon is referred to as "rush to motorization." Motorization rate is 451 cars per 1000 inhabitants and is comparable to the value of the indicator in the developed EU countries: Great Britain, Spain (Table 3).

The transport infrastructure, particularly road infrastructure, has not adjusted to such a large volume of transporting cargo and passengers. The length of motorways in Poland is only $857 \mathrm{~km}$, which constitutes $13 \%$ of the length of motorways in Italy, which is a country with a comparable area. This indicator looks much worse when compared to France, Germany, or even Hungary (Table 3). In Poland, the quality of the transport infrastructure is a fundamental problem: the technical condition, the lack of motorways, and a high-speed rail network.

The Polish economy in the EU is distinguished by its relatively high dynamics of growth. With the low overall level of the economic development, this argument can be an incentive for private foreign investors. The progressing economic growth generates increased demand for the transport of cargo and passengers. This is particularly noticeable in the road transport, including both freight transport and passenger transport by cars. This situation forces the rapid improvement of the condition of the infrastructure, which is not adjusted to current and future transport needs. The heavy traffic is an important argument that justifies the construction of motorways in the PPP system.

Table 3. Basic indicators of road transport, 2010 [31]

\begin{tabular}{|c|c|c|c|}
\hline Country & $\begin{array}{c}\text { Area } \\
\mathrm{km}^{2}\end{array}$ & $\begin{array}{c}\text { Lenght of } \\
\text { motorway } \\
\mathrm{km}\end{array}$ & $\begin{array}{c}\text { Number of } \\
\text { passenger cars } \\
\text { per 1000 } \\
\text { inhabitants }\end{array}$ \\
\hline EU27 & 4325 & 69468 & 477 \\
\hline France & 344 & 11392 & 501 \\
\hline Germany & 357 & 12819 & 517 \\
\hline Italy & 301 & 6668 & 606 \\
\hline Spain & 506 & 14262 & 480 \\
\hline United Kingdom & 244 & 3673 & 470 \\
\hline Poland & 313 & 857 & 451 \\
\hline Czech Republic & 79 & 734 & 427 \\
\hline Hungary & 93 & 1477 & 299 \\
\hline Slovak Republic & 49 & 416 & 307 \\
\hline
\end{tabular}

\subsection{Economic Policy of the Government and Experience with PPP Projects}


In Central and Eastern Europe, political and economic transformation began in the late 80 's. After 45 years of functioning in the system of a centrally planned economy, the governments of these countries started to introduce market mechanisms, to privatize selected sectors of the economy, and form a financial market. In the early 90's, even left-wing governments, aimed at public property, actively supported market actions, privatization and deregulation. The pace of these processes was slowed down in the next period, from the mid-90's till 2007 [34]. Privatization and deregulation changed the place of the private sector in the economy and enabled to run a business by private sector in areas considered earlier as a domain of public authorities. The started processes encouraged private investors to become involved in different areas of public activity, including infrastructure investments. Thus, the development of different PPP forms began in these countries after 1990, while in Great Britain partnership has been used since the early 80 's. The British market is the most developed PPP market in Europe, which is depicted in Figure 4. The data covers all sectors in which PPP projects are implemented (total PPP) and have a value of over 5 million euros [35].

In the years 1987-2004, the British government entered into 677 contracts worth 65 billion euro [35]. For comparison, the value of the whole PPP market in Europe during the highest growth in 2007 was approximately 30 billion euro [36]. The fact that until 2004 almost all projects had been realized in Great Britain also draws attention. In subsequent years there was a change in proportion between Great Britain and other European countries - in the former the number of projects began to decline, and in the latter it had been growing rapidly until the economic crisis in 2008 .
Despite these changes, Great Britain still remains the PPP leader in Europe.

The development level of the PPP market in particular European countries can be investigated by analysing the results of research conducted by A. Kappeler - a European Investment Bank expert. The outcome of the research is shown in Table 4 [35]. The presented research indicates that, apart from Great Britain, partnership plays a prominent role in such countries as Spain, Portugal, Ireland, France, and Belgium. In these countries, especially in Portugal and Spain, mainly capital-intensive transport infrastructure projects are implemented in the PPP formula. In addition, Germany and Italy have a well-developed PPP market. However, in contrast to the previous group, quite a large number of projects of a relatively low value are implemented there. Additionally, the countries are characterized by a greater diversity of sectors in which PPP projects are implemented. In Germany, for example, the highest number of projects were executed in the following sectors: education, sports, and accommodations - more than in the road sector. The Central European countries are characterized by a small number of large transport projects launched by the government, including the construction of motorways in Poland and Hungary as well as an electronic toll system for trucks in Slovakia. Only in the Czech Republic, the vast majority of projects were planned at the municipal level and the dominant sectors were public services (real estate management, maintenance of municipal infrastructure), housing construction, sports, and education. However, in 2009, pilot PPP projects in the field of road and railway infrastructure, initiated by the government, were started [37,38].

\section{Financing requirements in $€$ bln (bars)}

No of deals (lines)

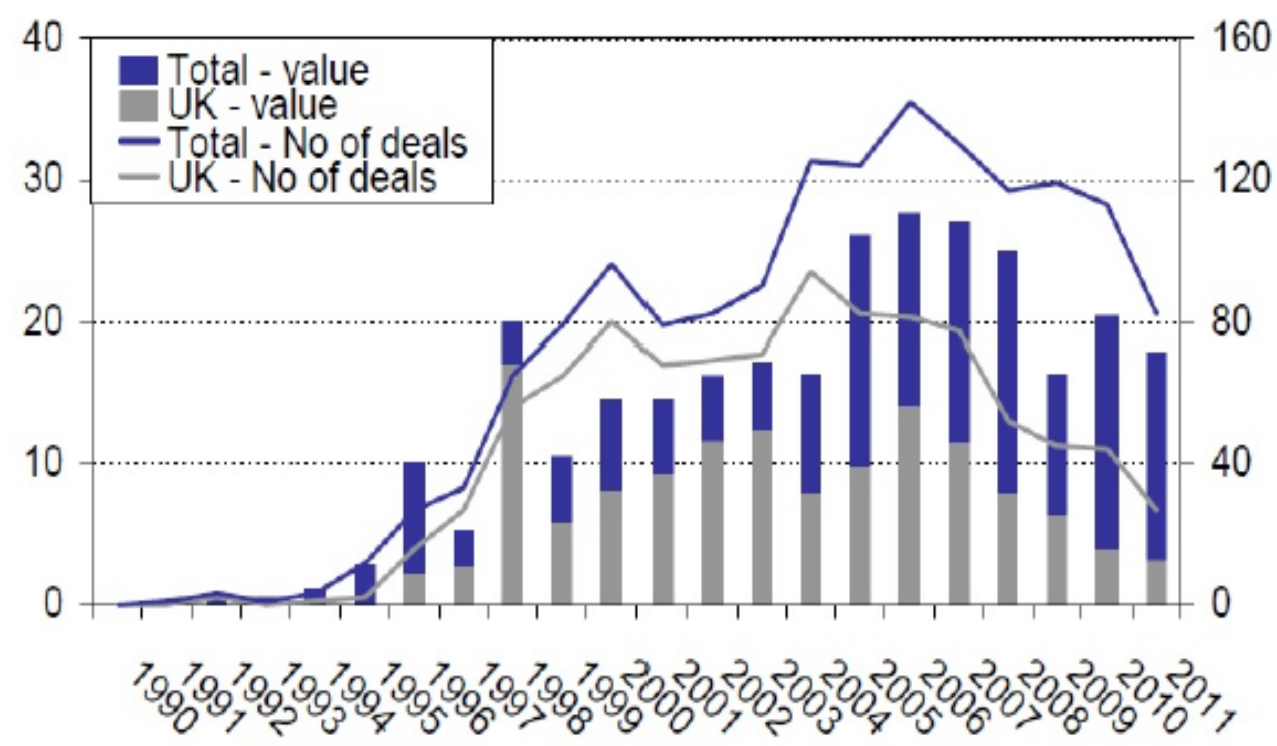

Figure 4. Financing requirements and number of deals reaching financial close [35] 
Table 4. Basic PPP indicators in EU countries, 2004 - 2011 [35]

\begin{tabular}{|c|c|c|c|}
\hline Country & $\begin{array}{c}\text { Total number } \\
\text { of PPP deals reaching } \\
\text { financial close }\end{array}$ & $\begin{array}{l}\text { Aggregate financing needs of } \\
\text { PPPs reaching financial close } \\
\text { in } € \mathrm{mln}\end{array}$ & $\begin{array}{l}\text { Aggregate financing needs of } \\
\text { PPPs reaching financial close } \\
\text { in } \% \text { of GDP }\end{array}$ \\
\hline Austria & 2 & 1287 & 0,0006 \\
\hline Belgium & 18 & 4393 & 0,16 \\
\hline Bulgaria & 2 & 239 & 0,0 \\
\hline Cyprus & 1 & 658 & 0,0 \\
\hline Czech Republic & 5 & 151 & 0,0001 \\
\hline Germany & 83 & 7541 & 0,0004 \\
\hline Denmark & 6 & 328 & 0,0002 \\
\hline Spain & 122 & 27233 & 0,34 \\
\hline Finland & 2 & 710 & 0,0005 \\
\hline France & 98 & 23165 & 0,15 \\
\hline Hungary & 5 & 2484 & 0,33 \\
\hline Italy & 31 & 8727 & 0,0007 \\
\hline Ireland & 16 & 3387 & 0,25 \\
\hline Lithuania & 1 & 10 & 0,0 \\
\hline Latvia & 0 & 0 & 0,0 \\
\hline Luxemburg & 1 & 33 & 0,0 \\
\hline Netherlands & 10 & 4469 & 0,0005 \\
\hline Poland & 5 & 5437 & 0,22 \\
\hline Portugal & 30 & 11896 & 0,90 \\
\hline Romania & 1 & 20 & 0,0 \\
\hline Slovak Republic & 1 & 1193 & 0,27 \\
\hline Sweden & 1 & 1104 & 0,0004 \\
\hline United Kingdom & 502 & 65803 & 0,45 \\
\hline
\end{tabular}

In Poland, the processes of deregulation and privatization took place along with systemic changes which began in 1989 . In 1994, the government passed a law which allowed the implementation of road investments by the private sector, and in 1997, first concessions for the construction and operation of motorways were granted. The government was the initiator of these actions. As a result, in the years 2000-2012, private partners, which can be defined as private consortia, in the concession system completed the following:

- The construction of Świecko-Konin section of A2 motorway of $255 \mathrm{~km}$.,

- The construction of Gdańsk-Torun section of A1 motorway of $152 \mathrm{~km}$., and

- The construction of Katowice-Kraków section of A4 motorway of $61 \mathrm{~km}$ by means of adjustment for the purpose of collection of tolls.

These are all major transport projects implemented in Poland with the participation of a private partner. Altogether, private consortia have constructed and operated approximately $23 \%$ of total length of the motorway network in Poland. In some European countries, the share of PPP investments in the whole major road network amounts to an average of $50 \%$ [39].

Apart from the motorway building projects that have already been finished, other PPP undertakings, of a lower value, have been implemented in Poland. They are being initiated by public authorities at different levels - regional, country, and city. This market began to develop in 2009, because only then were the legal regulations established that corresponded to specifics of PPP (this problem will be discussed in the next section of the article). The value of the whole PPP market and the number of projects executed in the years 2009-2012, calculated on the basis of notices published in the Polish Public Procurement Bulletin and/or the Official Journal of the EU as well as the Polish base of PPP projects [40], are presented in Figures 5 and 6. The data differs from the information shown in Table 4, because Table 4 does not include smaller projects that have a value below 5 million euro.

Generally, the Polish market has the upward trend, the value of projects increased over three times within four years. However, this constitutes only 6\% of European PPP market value, whose value was estimated at 11.7 billion euro in 2012 [36]. The number of announcements about investment projects to be implemented in the PPP formula amounts to 30-60 annually. However, only $19 \%$ of the announcements are actually finalized in the form of PPP contracts. This is a serious problem that results from the lack of experience of the Polish institutions in the practical application of PPP and other factors that will be analysed later in this article. 


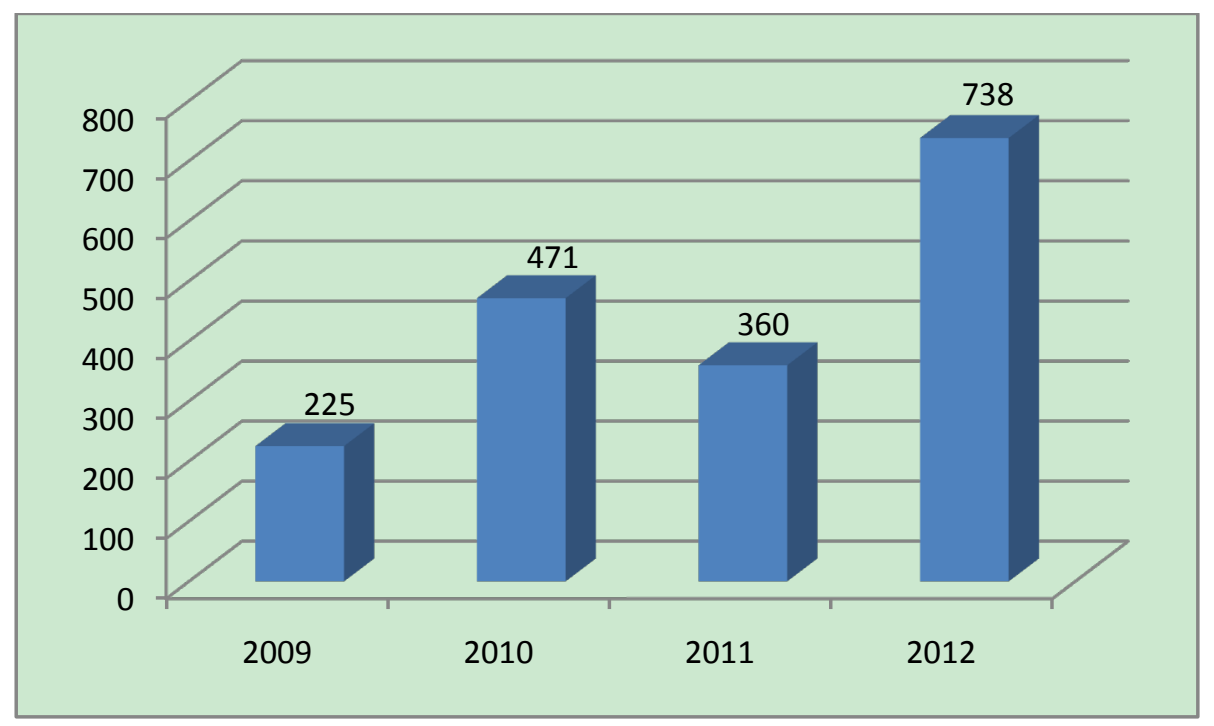

Figure 5. The value of PPP projects in Poland, in $€$ million $[40,41]$

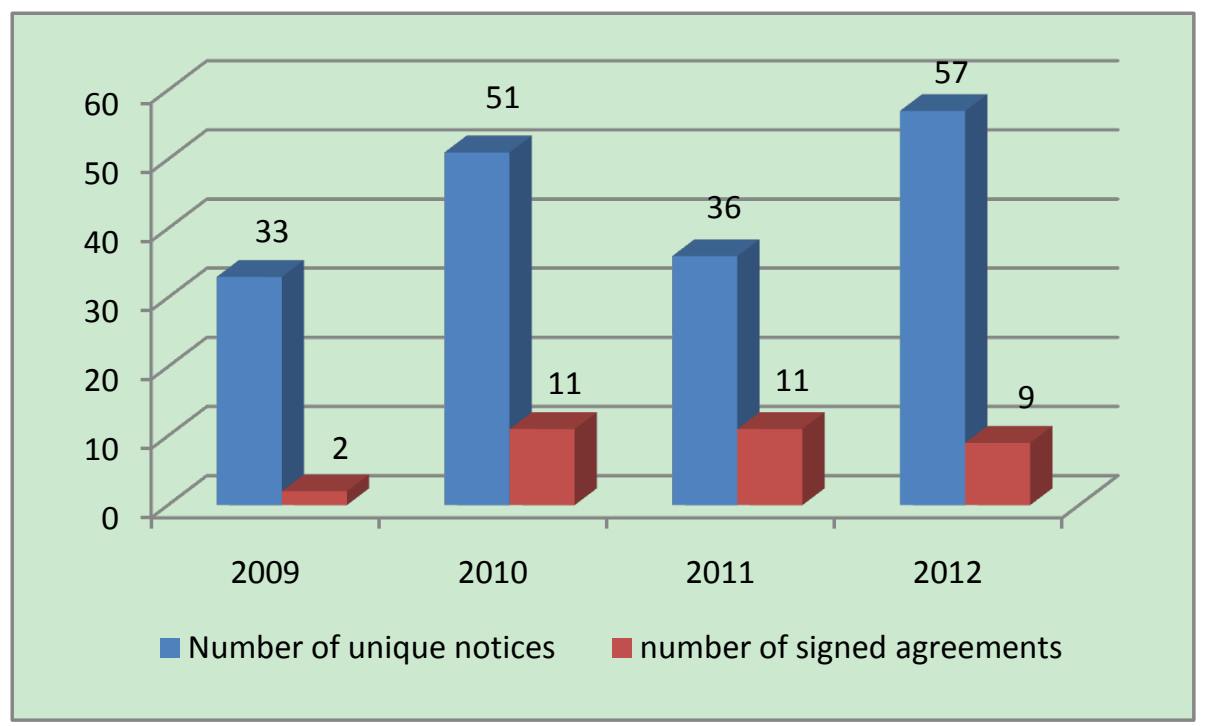

Figure 6. The number of unique notices and signed PPP agreements in Poland [40]

The level of development of the PPP market in Poland, it can be compared with the general expenses of public authorities for investments. In 2009, the value of PPP projects accounted for $2.3 \%$ of these expenditures , and in subsequent years, it was as follows: $2010-4 \%, 2011-$ $3.4 \%$. In the EU in 2007, the PPP projects accounted for about $4 \%$ of all investments in the public sector [42]. Against this background, the value of undertakings in Poland is fully comparable, considering the relatively short period of the application of this formula.

The analysis leads to the conclusion that, without strong government support for the processes of privatization and deregulation for an extended period of time, we cannot talk about creating conditions for the development and effective implementation of PPP. The position of Great Britain in the PPP market is a consequence of the economic policy, which was initiated by the Conservative government of Margaret Thatcher, and which was continued, with different determination, by successive governments. The influence of the economic doctrine of the government on the development of PPP is particularly evident when comparing the position of Great Britain with Scandinavian countries in Europe (Denmark, Sweden, Finland). Despite the fact that those countries have an established democratic system and a good and stable macroeconomic condition, they take lower positions than the countries of Central Europe - Poland, Hungary, and Slovakia. The example of Great Britain also shows that using different forms of PPP for a long time and having a lot of experience determine the success of projects.

The PPP market in Poland is being shaped in the conditions of setting priorities of the economic policy, in particular the place and role of the private sector. The logical consequence of these conditions is its low level of maturity in comparison to the markets of the leading EU countries. The Polish market is a market of an average value and number of implemented projects. It can be described as 
"under construction market" with little experience.

\subsection{The level of development of the financial market}

The research conducted by the World Economic Forum indicates that the United States, Great Britain, Canada, Switzerland, Asian markets - Hong Kong, Singapore, Japan and Australia (the list presented in Table 5) were the most developed financial market in 2008-2012. Poland was ranked $37^{\text {th }}$ in 2012 and improved its position in comparison with 2008, which may indicate that the market develops slowly. Also, it is ranked high compared to other Central Europe markets. Poland has a well-developed, non-bank financial services market, including insurance services, especially the stock market. The banking sector, however, is considered to be underdeveloped [43]. Furthermore, in recent years, Polish banks have focused on credits granted to households. These conditions are not favourable to private investors and discourage them from financing transport infrastructure projects that are capital-intensive.

Table 5. The Financial Development Index 2012 rankings: Comparison with $2008[43,44]$

\begin{tabular}{|c|c|c|}
\hline Country & $\begin{array}{l}2012 \\
\text { Rank }\end{array}$ & $\begin{array}{c}2008 \\
\text { Rank }\end{array}$ \\
\hline Hong Kong SAR & 1 & 8 \\
\hline United States & 2 & 1 \\
\hline United Kingdom & 3 & 2 \\
\hline Singapore & 4 & 10 \\
\hline Australia & 5 & 11 \\
\hline Canada & 6 & 5 \\
\hline Japan & 7 & 7 \\
\hline Switzerland & 8 & 9 \\
\hline Netherlands & 9 & 13 \\
\hline Sweden & 10 & 35 \\
\hline Czech Republic & 35 & 41 \\
\hline Poland & 37 & \\
\hline Slovak Republic & 38 & 44 \\
\hline Hungary & & 43 \\
\hline
\end{tabular}

The European Investment Bank was the main bank crediting the construction of motorways in Poland. Its share in the total investment costs reached the level of $33 \%$ to $78 \%$, depending on a project. Loans were also granted by commercial banks, whose share ranged between $22 \%$ to $46 \%$. The company that constructed the A1 motorway obtained credits from foreign banks - the Nordic Investment Bank and the Swedish Export Credit Corporation. In turn, the consortium building the first section of the A2 motorway was granted credits by 11 foreign and Polish commercial banks (including BBVA S.A., Bank Pekao S.A., BRE Bank S.A., Caja Madrid, Calyon, Deutsche Bank AG, Espirito Santo Investment, KfW IPEX-Bank GmbH, PKO BP, Societe Generale, WestLB) and by French Credit Lyonnais and German Commerzbank for the construction of the second section [45]. When analysing the access that Polish private investors have to external funds, it is worth paying attention to the fact that it takes a lot of time to create a financing structure and achieve "financial closure" of the project. Licenses for the construction and use of the A1 and A2 motorways were awarded to companies in 1997, while the financial closure of the first section of the A1 motorway was reached in 2005 and in 2008 for the second section. In the case of the A2 motorway, it was 2000 and 2009.

The concession for the construction of another Stryków Pyrzowice section of the A1 motorway is an interesting study of cases in the context of the possibility to obtain external funding by Polish consortia. The contract for the construction and operation of the motorway was signed on 22 January 2009. The total investment cost, including debt service, was estimated at about 2 billion euro. The company agreed in the contract to ensure full financing for the investment by 22 January 2010. The European Investment Bank granted it a credit of 1100 million euro, while commercial banks, to which the company applied for a loan, demanded it to repay the credits within ten years due to the economic crisis. Such a solution was not accepted by the government, since it meant the accumulation of funding for the concessionaire in a much shorter period of time (charges for availability). The situation could undermine the stability of the budget of the National Road Fund, which is responsible for settlements with concessionaires. Due to the conditions, the company did not receive funding from commercial banks. The credit granted by the EIB was not enough to reach financial closure. The terms of the agreement were not met, and the company lost the concession and the section of the motorway is being constructed in a traditional system, from public funds. At the same time, in the period 2009-2010, another concessionaire lost its concession for the construction of the Stryków-Konotopa section of the A2 motorway, also as a result of problems to obtain financial resources [46]. During the financial crisis, banks set more strict lending policy, making it much more difficult for Polish private investors to get external funding.

The Polish financial market does not have effective mechanisms for financial inter mediation and does not offer such an easy access to capital and financial instruments as Western European countries. Efforts to achieve financial close of PPP projects, made for several years, confirm the inability to obtain financing for projects in Poland. The Polish government does not influence or place pressure on Polish banks to create good credit conditions for the private sector involved in financing infrastructure projects. In the case of large road projects, the funding structure is based on credits granted by the EIB. However, in the current 
economic situation in the EU, credits granted by the EIB for PPP projects decreased from 2.4 billion euro in 2010 to 1.5 billion euro in 2011 [35]. Therefore, the Polish government plans to construct more motorway sections in the form of a public-private partnership after a significant improvement in the financial market occurs.

\subsection{The level of competition in the public procurement market}

The European Commission research shows that the average number of bids made in tendering procedures for a public procurement in 30 countries of the European Economic Area EEA in 2010 was 5.4 bids in a tender. The largest number of offers was in Spain - 8.8, Germany - 7.6 and in the UK - 6.4. In Poland, the average number of bids was 3.1 and there were fewer offers only in Estonia - 2.8 and Slovakia - 2.1 [47]. The Polish Public Procurement Office obtained comparable data, and the problem of a small number of bids concerns not only European tenders, but also the national ones.

In the years 1996-97, tenders for the construction and operation of the A1 and A2 motorways were announced. Only two companies, which responded to the A1 motorway announcement, met the conditions of the tender. Regulations being in force then demanded the participation of at least three entities in the qualification procedure. The lack of the requested number of participants was a ground for cancelling the tender. However, the bid evaluation team decided to continue the proceedings, and only one company participated in the second stage and the tender was settled without the competition. The lack of companies' interest in participation in tenders was also characteristic for the tender announced in 1997 for appointing the concessionaire of construction and operation of the A4 section of the motorway Wroclaw - Katowice. In the set deadline for submission of bids, only two companies purchased the specifications of preliminary classification conditions. The third participant in the classification, required with provisions, was acquired only as a result of postponing the deadline for the submission of bids two times by the Minister. After ten years of experience, in 2006, there was greater competition in the tender for construction of the next sections of A2 and A1 motorways. From nine consortia which participated in both tenders, the committee chose three of each, and they were invited for tendering in the second stage of the proceeding [48].

It is possible to notice problems with obtaining private investors in tenders concerning less capital-intensive transport investments. Thirteen companies participated in the tender announced in 2011, which concerned the reconstruction and maintenance of $12 \mathrm{~km}$ of the provincial road (regional road, of lower category). However, this did not guarantee the success of the project. The tender was cancelled due to the high level of rates proposed by companies. Even in tenders for the construction of paid car parks in cities, which is a popular area for PPP projects (in
2010,30 projects were implemented), the number of offers is relatively small. In 2011, in one city (Bielsko-Biala), there were 3 , and in another city (Bydgoszcz) - 5 [46].

The conducted analysis confirms the low intensity of competition in the public procurement market of transport infrastructure. This situation applies to both motorways and projects with far less value, capital-intensity. Poor competition between investors hampers the choice of a better supplier and conducting ex-ante evaluation as well as worsens the negotiation position of institutions and public authorities.

\subsection{The Legal System}

The first act that made it possible to implement road projects by the private sector was created in 1994. It set the conditions for preparing the construction of motorways, licensing rules and concluding contracts for the construction and operation of toll motorways. The Act, however, did not offer the possibility of financial support to private entities by the state, which was required by foreign institutions co-financing motorways. Therefore, the Act was amended in 2000 and another source of financing introduced. Also, the National Motorway Fund was established. The fund received budget grants for construction and funds from the state budget for guarantees and sureties for the concessionaire that was granted a bank credit. Another amendment to this Act was introduced in 2004, when the National Road Fund was established. It took over the responsibilities of the previous Fund. The National Road Fund finances the preparations for the construction and maintenance of motorways, expressways, and other roads.

The first Act that offered the possibility to use PPP by public authorities - provincial, county and city - was introduced no earlier than in 20051. The Act required public authorities to carry out a very complex and detailed analysis of a PPP project at the pre-implementation stage. Such analysis generated great costs, which discouraged local governments. As a result, no project was implemented when the Act was in force. At the time of adoption, the Act was considered by the economic environment to be one of the most important acts passed by the then Parliament, while described as "dead" when in force. A new, more flexible act on public-private partnership, which is currently in force, was adopted in 2008. The Act triggered real implementation of different forms of PPPs. The market of smaller PPP projects, excluding motorways, started to develop no earlier than in 2009.

The problem that has not been solved by the Polish legislative bodies concerns the assessment of the influence of liabilities arising from PPP contracts on the level of public debt. An important added value of PPP projects is the possibility not to include them in the budget; therefore, there is no direct impact on public finances. PPP contracts include two main issues, which determine their influence on the level

1 Does not apply to construction and use of motorways 
of debt. These are the following:

- Actual financial obligations that a public entity owes to a private partner; and,

- Risk-sharing, on the basis of which it is decided whether public obligations arising from them are taken into account when calculating debt ratio.

The first issue concerns possible remuneration paid to a private investor, which is statutorily an expense having an impact on the level of debt. Depending on the type of infrastructure and provisions of the contract as well as the form of remuneration, in whole or in part, it burdens the public budget. The issue is regulated by Polish laws and regulations of the Minister of Finance.

The problem of risk-sharing and the assessment of the impact it has on the level of public debt, however, was not regulated by law. The guidelines of the European System of National and Regional Accounts, which were prepared by Eurostat [49], are very helpful in solving the issue. In Poland, institutions and state agencies, such as the Central Statistical Office, the Ministry of Regional Development, the Ministry of Economy, prepared documents that help to follow the guidelines formulated by Eurostat. However, the documents do not have the force of law. Local public authorities continue to face difficulties when trying to determine the impact of PPP contracts on the level of debt and are afraid of adapting this model, especially in the situation when the debt of the local government entities increases quickly. The ratio of liabilities to the general revenue of the local governments was $19 \%$ in $2005,33 \%$ in 2010 , and $38 \%$ in 2011 [32]. Some big cities, like Kraków, Wrocław, Toruń, have already exceeded the limit of $60 \%$ of the liabilities to revenue, which is established by law. The lack of funds leads to the situation when local authorities would like to use PPP, but at the same time they are afraid of a debt increase and possible repercussions.

When analysing the problem of the impact of PPP contracts on the level of public debt in relation to the construction of motorways, it should be noted that these investments have had different degrees of influence on the state budget. The first two projects (the section of the A2 motorway between Nowy Tomyśl and Konin and the A4 motorway) did not generate public debt, because the state had no influence on the level of charges paid by users. Revenues from the tolls formed the basis for the service of a debt for the construction of the motorways. In the case of the section of the A1 motorway between Gdańsk and Torun and the section of the A2 motorway between Świecko and Nowy Tomyśl, in turn, credits for the construction were on planned revenues from charges for the so-called "availability," which is paid to investors from the National Road Fund. In such projects, the state has influence on the level of charges, traffic risk is the risk faced by the public party. Thus, the projects have an influence on the level of public debt. It is worth mentioning here about the construction of other sections of the A1 and A2 motorways in the form of a public-private partnership. In the case of both projects, the government tried to combine the possibility to control charges by the public party and transfer most of the risks to the private consortium. Unfortunately, the government failed to achieve its goal, the projects did not achieve financial closure and were eventually implemented in the traditional model, namely, financed only from public funds.

The practice of implementing projects in the form of PPP revealed problems that were not included in the current legislation. The period in which changes were made and appropriate legal solutions developed was long, and in some cases, it lasted six years. Even today, there are no clear, universally applicable regulations regarding the impact of obligations arising from PPP contracts on the public debt. This is another problem that remains unsolved, referred to by local public authorities as PPP "hang-up".

Table 6. The number and structure of PPP entities in European countries, 2010 [46,50]

\begin{tabular}{|c|c|c|c|c|}
\hline Country & Number of entities & public & private & public - private \\
\hline Netherlands & 3 & 3 & - & - \\
\hline Belgium & 1 & 1 & - & - \\
\hline Switzerland & 1 & - & 1 & - \\
\hline France & 3 & & 1 & 1 \\
\hline Germany & 13 & 8 & - & 5 \\
\hline Ireland & 4 & 4 & - & - \\
\hline Spain & 1 & - & - & 1 \\
\hline Italy & 2 & 1 & - & 1 \\
\hline Portugal & 1 & 1 & - & - \\
\hline United Kingdom & 15 & 11 & 1 & 1 \\
\hline Czech Republic & 3 & 2 & - & - \\
\hline Poland & 2 & - & 2 & - \\
\hline Slovak Republic & 3 & 1 & 2 & - \\
\hline Hungary & 1 & 1 & - & \\
\hline
\end{tabular}




\subsection{The Institutional preparation (institutional capacity)}

Public entities - national, regional - play a very important role in the process of practical application of PPP as they perform coordination and analytical functions: they assess the economic effectiveness of individual projects. Table 6 shows the number and structure of PPP entities that operate at the national level in selected European countries.

As far as the analysed countries are concerned, only Switzerland, Spain and Poland have no public centres dedicated to PPP. In the countries that are PPP leaders, namely Great Britain and Germany, the number of public institutions dedicated to PPP is the highest. Establishing PPP-dedicated entities by the central administration is a consequence of the country's policy in relation to the role of PPP in addressing public needs. As regards countries that adopt a specific strategy on the use of PPP, public institutions play a major role in the implementation of the strategy. They primarily serve coordination and analytical functions, which means that the institutions assess the economic efficiency of individual projects. Additionally, they promote standards of good practices as well as standards of training and promotion practices.

In Poland, the government administration takes initiatives which encourage partnerships and promote its use in public activity. Here we can mention the most important ones, undertaken jointly by the Ministry of Regional Development, the Ministry of Economy, the Ministry of Infrastructure, and the Ministry of Finance:

- $\quad$ The PPP platform established in 2011; its main aim is to exchange information and good practices, as well as provide access to information materials about partnership; it has an open formula for all public organisations,

- The PPP project base containing market news and publications about partnership, which are available on a website [40],

- MAPPP, a national organization of experts established in 2005, with the role to serve both state and local government entities as well as other subjects interested in implementing projects in the PPP formula.

However, the actions of government administration have been carried out only in recent years and are more informative rather than advisory. In Poland, private organizations and institutions supporting the PPP function more actively. The foundation, the PPP Institute, which was founded in 2003, was the first of them. Its major purpose is education in the area of PPP and specialized consulting in preparing PPP investments from the formal, legal, and economic side. Another undertaking was the establishment of the foundation, the PPP Centre, in 2008. It is a civil, independent institution which aims to meet important public needs through significant acceleration of private investments in this part of the economy for which the state has no money. The PPP centre was founded by 41 entities including banks, law firms, consulting companies, firms, regional development agencies, foundations, associations, chambers, and business agencies. In the Polish PPP market, there is also a private consulting firm Investment Support. It supports local authorities and private companies in the preparation and execution of public-private investments, especially in revitalization projects and from the health care sector.

Analysing the problem of institutional preparation for promoting and implementing PPP, one should pay attention to the qualifications of employees. Readiness as well as organisational and competence maturity of employees of the public administration for implementation of projects certainly determine their success. This issue was the subject of research carried out in 2011 [46]. The assessment of knowledge and experience in the field of PPP showed that $89 \%$ of respondents heard about PPP, but only $4 \%$ applied it in practice. The highest percentage of individuals who have realised or have ever prepared for investments in PPP formula takes place in medium-sized cities with county rights (41\%). Among the respondents who had heard of the PPP the majority assess their knowledge on the subject as average (53\%), and only few as very good (11\%) . The main source of knowledge and information of public administration about the PPP are general press articles (49\%), other media (45\%) and trainings (42\%). Assessment of local decision-makers' knowledge on PPP-related topics showed it was on the average level. The organizational structures of offices very rarely (8\%) select individuals dealing only with PPP issues.

In Poland, public consulting institutions that would assist local authorities with preparing projects and would conduct economic appraisal free of charge have not been formed. The existing Internet websites have mainly informational character. A lack of government support for the PPP results in a very poor preparation of public sector workers. PPP qualifications and skills in Polish public, government, and local government institutions are only at the stage of creation.

\section{Conclusions}

The government's economic policy in relation to privatization and deregulation processes is the primary determinant of the application of PPP. Poland is a country with a relatively "young" democracy, in which the priorities of the economic policy are still being established, especially those concerning the place and role of the private sector. In comparison to "old" EU countries, it is characterized by a lower level of economic development. These worse macroeconomic conditions have an influence on some factors relevant to the development of PPP. The low level of development of the Polish financial market and strict policy followed by banks (Bazylea III) during the economic crisis were one of the reasons for the difficulties in reaching financial close of projects, and even resigning from the construction of motorways using the PPP system. The list of unfavourable factors also includes the low level of 
competition in the public procurement market. Another problem is the legal system, which is not fully adapted to the specificity of PPP projects. Due to relatively short experience in practical implementation of PPP, it takes even several years to work out appropriate legal solutions. The government does not establish public institutions that would be in charge of PPP projects, which would help to prepare and assess projects and impose no charges for this service. Lack of government policy supporting and promoting partnership results in a low level of competence of employees of public administration at all levels. As a result of these conditions, the Polish PPP market has low value and is characterized by a low number of projects being implemented, and thus can be described as "an under construction market." At the same time, the market develops rapidly and the public authorities at lower levels (e.g. municipal) attempt to implement PPP with great determination.

In the aspect of the conditions mentioned above, the challenge for the Polish government is to establish objectives and expectations with respect to public-private partnership and identify the most suitable areas to implement it. However, it is also of great importance to accelerate legislative processes and refine regulations, especially which local governments actively support the government and make proposals for amendments to the existing legislation. Another step should be to establish an organizational unit (e.g. a department at the government level), which would fulfil the function of a consulting and operational centre for partnership. One of the responsibilities of the units would be to train specialized and competent civil servants, who could be responsible for the implementation of PPP.

Public-private partnership should be considered optional, as one of the possible models that can be adopted to finance public investments. However, there is a strong need to co-finance public investments by private entities (companies), which is connected with an increasing deficit of the public sector. Paradoxically, the factor may be the one that will force and urge the government to take actions aimed at developing effective methods of the implementation of PPP projects.

\section{REFERENCES}

[1] G. Aberle. Private Verkehrswegefinanzierung. Aus Fehlern Lernen. Internationales Verkehrswesen, Nr. 57, 2005.

[2] E. Quinet, R. Vickerman. Principles of transport economics. Cheltenham UK/Northampton, MA, USA, Edward Elgar, 2004.

[3] B. Flyvbjerg, N. Bruzelius, W. Rothengatter. Megaprojects and Risk: An Anatomy of Ambition. Cambridge University Press, UK, 2003.

[4] K.A.K. Devapriya. Governance issues in financing public-private partnership organisations in network infrastructure industries. International Journal of Project Management, Volume 24, No. 7, p.p. 557-565, 2006.

[5] G. Hodge and C. Greve. The Challenge of Public Private Partnerships. Learning from International Experience. Edward Elgar, Cheltenham, UK, 2005.

[6] D. Osborne, T. Gaebler. Reinventing government - how the entrepeneurial spirit is transforming the public sector. Plume, New York, 1993.

[7] R. Mu, M. de Jong, E. ten Heuvelhof. A Typology of Strategic Behaviour in PPPs for Expressways: Lessons from China and Implications for Europe. EJTIR, Issue 10(1), 2010 .

[8] Decision No 884/2004/EC of The European Parliament and of The Council of 29 April 2004 amending Decision No 1692/96/EC on Community guidelines for the development of the trans-European transport network. EN Official Journal of the European Union, L 167, 30.4.2004.

[9] Green Paper on Public-Private Partnerships and Community Law on Public Contracts and Concessions. European Commission, Directorate-General Regional Policy, Brukssels, 2004.

[10] Private Participation in the Transport Sector. Transport Papers, TP-24, World Bank, Washington, 2009.

[11] Public-Private Partnerships: models and trends in the European Union. European Parliament, Internal Policy Department, Brukssels, 2005.

[12] Guidelines for Successful Public - Private - Partnerships. European Commission, Directorate-General Regional Policy, Brukssels, 2003.

[13] Resource Book on PPP Case Studies. European Commission, Directorate-General Regional Policy, Brukssels, 2004.

[14] A Guide to Guidance. Sourcebook for PPPs. EPEC, EIB, 2010.

[15] White Paper. Roadmap to a Single European Transport Area - Towards a competitive and resource efficient transport system. COM(2011) 144 final, Brukssels, 2011.

[16] O. Hart. Incomplete contracts and public ownership: remarks, and an application to publice-private partnerships. The Economic Journal, 113(March), p.p.69-76, 2003.

[17] A. Kappeler, M. Nemoz. Public-private partnerships in Europe - before and during the recent financial crisis. Economic and Financial Report. European Investment Bank, Luxembourg, 2010.

[18] M. Hammami, J. F. Ruhashyankiko, E. Yehoue. Determinants of publice-private partnerships in infrastructure. IMF, Working Paper WP/06/99, 2006.

[19] P. Galilea, F. Medda. Does the political and economic context influence the success of a transport project? An analysis of transport public-private partnerships. Research in Transportation Economics, No 30, p.p.102-109, 2010.

[20] E. S. Savas. Privatizing the Public Sector: How to Shrink Government. Chatham House, New York, USA, 1982.

[21] B. Bortolotti, M. Fantini, D. Siniscalco. Privatisation around the world: evidence From panel data. Journal of Public 
Economics, 88(1-2), p.p.305-332, 2003.

[22] B. Bortolotti, P. Pinotti. Delayed privatization. Public Choice, 136 (3-4), p.p.331-351, 2008.

[23] H. Pitlik. A race to liberalization? Diffusion of economic policy reform among OECD-economies. Public Choice, 132(1), p.p.159-178, 2007.

[24] N. Potrafke. Does government ideology influence deregulation of product markets? Empirical evidence from OECD countries. Public Choice, 143, p.p.135-155, 2010.

[25] D. Mansoor, M. Klein. Government Support to Private Infrastructure Projects in Emerging Markets. Policy Research Working Paper, No. 1688, World Bank, Washington, 2007.

[26] J. Butkiewicz, H. Yanikkaya. The effects of IMF and world bank lending on long-run economic growth: an empirical analysis. World Development, 33(33), p.p.371-391, 2005.

[27] H. Priemus, B. Flyvbjerg, B. van Wee. Decision-making on Mega-projects: Cost-benefit Analysis, Planning and Innovation (Transport Economics, Management and Policy Series). Elgar Edward, UK, 2008.

[28] F. Medda, G. Carbonaro. Publice-private partnerships in transportation: Some insights from the European experience. EIB, Working Paper, 2007.

[29] K. Pistor, M. Raiser, S. Gelfer. Law and Finance in Transition Economies. Economics of Transition, Volume 8, No. 2, p.p. 325-368, 2000.

[30] D. Parker, K. Hartley. Transaction costs, relational contracting and public private partnerships: a case study of UK defence. Journal of Purchasing and Supply Management. Volume 9, No.3, p.p. 97-108, 2003.

[31] EU. Transport in figures - Statistical pocketbook 2013. www.ec.europa.eu (last accessed 18.08.2013)

[32] Statistical Yearbook of the Republic of Poland 2012. Central Statistical Office, Warsaw, Poland, 2012.

[33] The development of enterprises of public participation and of general economic interest in Europe since 1996. Their economic impact in the European Union. European Centre of Enterprises with Public Participation and of Enterprises of General Economic Interest, Brukssels, 2000.

[34] Ch. Bjørnskov, N. Potrafke. Politics and privatization in Central and Eastern Europe. Economics of Transition, Volume 19, Issue 2, p.p. 201-230, 2011.

[35] A. Kappeler. PPPs and their Financing in Europe: Recent Trends and EIB Involvement. European Investment Bank, Economic Studies Division, Luxembourg, 2012.

[36] Review of the European PPP Market in 2012. EPEC, 2013.

[37] European PPP Report 2009. EPEC, 2010.
[38] Review of the European PPP Market in 2010. EPEC, 2011.

[39] A. Kossak. PPP. Schlechtes Image ist hausgemacht. Internationales Verkehrwesen, $\mathrm{Nr}$ 3, 2011.

[40] ww.pppbaza.pl

[41] Rynek PPP w Polsce 2011. Investment Support, Warszawa, Poland, 2012. (Published in Polish); PPP market in Poland 2011. Investment Support, Warsaw, Poland, 2012.

[42] Mobilizing private and public investment for recovery and long term structural change: developing Private-Public Partnerships. Communication from the Commission to the European Parliament, Council, the European Economic and Social Committee and the Committee of the Regions, European Commission, Brussels, 2009.

[43] The Financial Development Report 2012. World Economic Forum, USA, 2012.

[44] The Financial Development Report 2008. World Economic Forum, USA, 2008.

[45] B. Zagożdżon. Sektor prywatny w finansowaniu infrastruktury drogowej - teoretyczne założenia PPP a praktyka (analiza studiów przypadków). Przegląd Komunikacyjny, Nr 11, Poland, 2005. (Published in Polish); B. Zagożdżon. The private sector in financing transport infrastructure - theoretical guidelines of PPP versus practice (the analysis of studies of cases). Communication Review, No 11, Poland, 2005.

[46] B. Zagozdzon. Czynniki determinujące wykorzystanie PPP w obszarze infrastruktury transportowej. Przegląd Komunikacyjny, Nr 1, Poland, 2013. (Published in Polish); B. Zagozdzon. Factors determining using PPP in the area of transport infrastructure. Communication Review, No 1, Poland, 2013.

[47] Evaluation Report Impact and Effectiveness of EU Public Procurement Legislation. European Commission, Brussels, 2011.

[48] B. Zagożdżon. Problemy integracji sektora publicznego i prywatnego przy realizacji inwestycji infrastruktury transportowej. w: M. Michałowska (red.). Procesy integracyjne wybranych systemów transportowych. Wydawnictwo Akademii Ekonomicznej w Katowicach, Katowice, Poland, 2007. (Published in Polish); B.Zagożdżon. Problems of integrating public and private sectors in implementing the investments of transport infrastructure. in: M. Michałowska (ed.). Integration processes of selected transport systems. Academy of Economics Publisher in Katowice, Katowice, Poland, 2007.

[49] Manual on Government Deficit and Debt. Implementation of ESA95. Edition 2012.

[50] PPP in Infrastructure Resource Center. Publications Office of the European Union, Luxembourg, 2012. (www.worldbank.org/ppp, last accessed 30.08.2013). 